\title{
Chemical Investigation on the Changes in Lysozyme during Heating ${ }^{\dagger}$
}

\author{
Fumitaka Hayase, Hiromichi Kato and Masao FuJMaki \\ Department of Agricultural Chemistry, \\ The University of Tokyo, Tokyo \\ Received January 16, 1975
}

\begin{abstract}
Chemical changes in lysozyme during heating at $150 \sim 250^{\circ} \mathrm{C}$ for 20 min were investigated by means of IR, ESR, and CD spectroscopies and gel permeation chromatography, and further a tryptic hydrolysate from the lysozyme heated at $200^{\circ} \mathrm{C}$ was analyzed by ion exchange chromatography. At $150^{\circ} \mathrm{C}$, polymerization through disulfide linkages was observed, and at $180^{\circ} \mathrm{C}$, both polymerization and degradation occurred. When the temperature was raised to $200^{\circ} \mathrm{C}$, remarkable changes in the structure of lysozyme, such as cleavage and recombination of peptide bonds, occurred. Over $200^{\circ} \mathrm{C}$, polymerization and degradation occurred more violently.
\end{abstract}

The elucidation of the thermal degradation mechanism of proteins is considered to be of importance from the food chemical point of view, especially as to cooking and heat processing of food materials.

In the previous papers, ${ }^{1 \sim 3)}$ the authors described on the decomposition and the racemization of amino acid residues of casein, lysozyme and poly-L-amino acids under roasting conditions. In the present work, the authors investigated on the changes in protein during heating by using various physical and chemical methods. Lysozyme was used as a pure protein sample and heated at various temperatures $\left(150 \sim 250^{\circ} \mathrm{C}\right)$ for $20 \mathrm{~min}$ and the resulting residues were analyzed by means of infrared, electron spin resonance and circular dichroism spectroscopies and gel permeation chromatography, and further a tryptic hydrolysate from the heated lysozyme was fractionated and analyzed in order to clarify the thermal degradation mechanism.

\section{MATERIALS AND METHODS}

Heating of lysozyme. Lysozyme from egg white (Seikagaku Kogyo Co., Ltd., $6 \times$ Crystallized), (10

$\dagger$ Studies on Roasting Changes in Proteins. Part VI. Part V: F. Hayase, H. Kato and M. Fujimaki, Eiyo to Shokuryo, 28, 39 (1975). Part IV, Reference 10).
$200 \mathrm{mg}$ ) was heated in a dry state at $150 \sim 250^{\circ} \mathrm{C}$ for $20 \mathrm{~min}$ under air with the apparatus described in the previous paper.11

Spectroscopies. Infrared spectra were measured with a JASCO Model IR-S in $\mathrm{KBr}$ tablets. Electron spin resonance (ESR) spectra of lysozyme during heating at 150,180 and $210^{\circ} \mathrm{C}$ were recorded using a JES-PE-3X Spectrometer in a pyrex sample tube (ca. $5 \mathrm{~mm}$, i.d.). Lithium TCNQ radical ( $\mathrm{g}=2.0046$ ) was used as a standard. Circular dichroism (CD) curves were obtained on a JASCO Model J-20. Heated lysozyme was dissolved in $1 / 15 \mathrm{M}$ phosphate buffer, pH 7.0 , at a concentration of $0.2 \%(\mathrm{w} / \mathrm{v})$.

Gel permeation chromatography. The lysozyme heated at various temperatures for $20 \mathrm{~min}$ was dissolved in $8 \mathrm{M}$ urea to prevent aggregation in solution. The $8 \mathrm{M}$ urea-soluble fraction was used as the starting material for gel permeation chromatography. It was done using a Sephadex G-100 column $\left(3.1 \mathrm{~cm}^{2} \times 50 \mathrm{~cm}\right)$ equilibrated with $8 \mathrm{~m}$ urea.

The Biuret reaction. Lysozyme samples heated at 150 and $180^{\circ} \mathrm{C}$ for $20 \mathrm{~min}$ were analyzed by the Biuret reaction ${ }^{4)}$ to determine the amount of peptide bond.

Tryptic hydrolysis of the heated lysozyme and isolation of peptide fragments. The method which had been used by Canfield ${ }^{5}$ to determine the primary structure of lysozyme in 1963, was applied to the heated lysozyme. The lysozyme heated at $200^{\circ} \mathrm{C}$ for $20 \mathrm{~min}$ was reduced with 2-mercaptoethanol to prevent disulfide exchange and then carboxymethylated. The resulted solution was dialyzed against distilled water to remove the excess reagents, low-molecular peptides and free amino acids. 
The non-dialyzable fraction was lyophilized. The carboxymethyl-lysozyme $(300 \mathrm{mg}$ ) thus obtained was hydrolyzed with trypsin (Miles). The conditions of enzymatic reaction were as follows: substrate concentration, $1 \%(\mathrm{w} / \mathrm{v})$; enzyme-substrate ratio, 2/100 (w/w); $\mathrm{pH} 7.5$; incubation temperature, $30^{\circ} \mathrm{C}$ and incubation time, $6 \mathrm{hr}$. The hydrolysate was adjusted to $\mathrm{pH} 2.2$ with formic acid and separated by ion exchange chromatography: a Dowex $50 \times 4$ column, $3.1 \mathrm{~cm}^{2} \times 150 \mathrm{~cm}$, column temperature, $35^{\circ} \mathrm{C}$. The separation was done by means of gradient elution with a pyridine-acetic acid system. An aliquot was pipetted from each fraction $(10 \mathrm{ml})$ and tested by the ninhydrin method.6) The each peak obtained was developed with paper chromatography: solvent system, butanol: acetic acid: water (4: 1:2); paper, Toyo Roshi No. 51 filter paper. Each main ninhydrin-positive spot on the each chromatogram was eluted with distilled water and concentrated. The concentrated samples were developed with thin layer chromatography: solvent system, butanol: acetic acid: water (4:1:2); adsorbent, Kieselgel G. Each main ninhydrin-positive spot on the each chromatogram was eluted with distilled water and concentrated. The each isolated peptide was hydrolyzed with $6 \mathrm{~N} \mathrm{HCl}$ at $110^{\circ} \mathrm{C}$ for $20 \mathrm{hr}$ and then amino acid composition of the hydrolysate was determined with a Hitachi Amino Acid Analyzer KLA-5.

Enzymatic activity of the heated lysozyme. Enzymatic activity of the heated lysozyme was measured using ethylene glycol chitin as a substrate. ${ }^{7,81}$ The enzymatic reaction was done as follows: substrate concentration, $0.4 \%(\mathrm{w} / \mathrm{v})$; enzyme-substrate ratio, $1 / 100(\mathrm{w} / \mathrm{w}) ; \mathrm{pH} 5.6$; incubation temperature, $40^{\circ} \mathrm{C}$.

\section{RESULTS}

Infrared absorption spectra of the heated lysozyme

Infrared spectra of the lysozyme heated at $150 \sim 250^{\circ} \mathrm{C}$ are shown in Fig. 1. Above $100^{\circ} \mathrm{C}$, an absorption at $1720 \mathrm{~cm}^{-1}$ appeared and increased. When the heated lysozyme was treated with $\mathrm{NaOH}$, the absorption at $1720 \mathrm{~cm}^{-1}$ disappeared, indicating that the absorption is due to the vibration stretching of carboxyl group. It is assumed that the carboxyl group is formed by cleavage of peptide bond or by oxidative decomposition of side chain of amino acid residue.

\section{Electron spin resonance spectra of the heated lysozyme}

As shown in Fig. 2a), the lysozyme heated at $150^{\circ} \mathrm{C}$ for $5 \mathrm{~min}$ revealed one radical in the same position as that of the $g$-marker corresponding to free electron spin. The radical

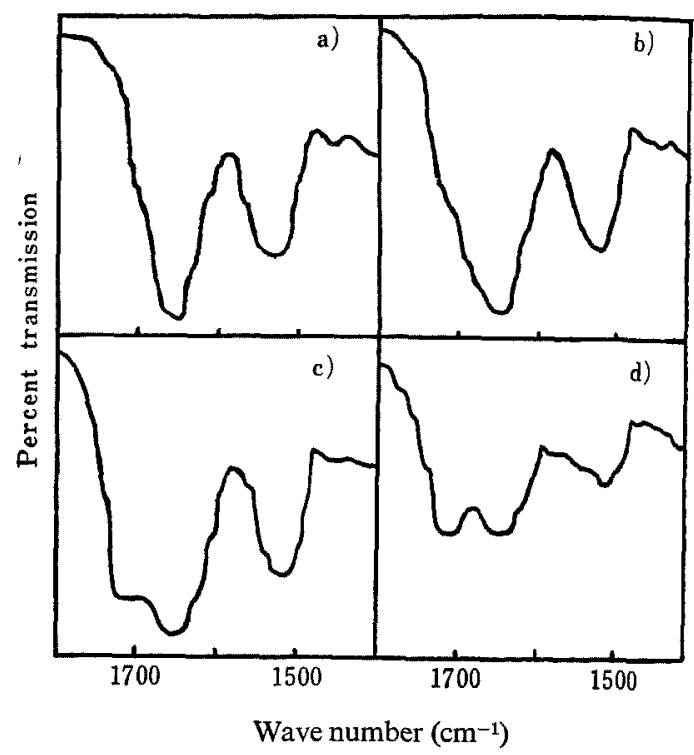

Fig. 1. Infrared Spectra of Lysozyme Heated at Various Temperatures for $20 \mathrm{~min}$.

a) $150 \sim 190^{\circ} \mathrm{C}$, b) $200^{\circ} \mathrm{C}$, c) $230^{\circ} \mathrm{C}$, d) $250^{\circ} \mathrm{C}$.

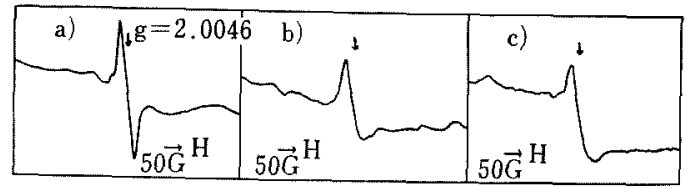

FIG. 2. ESR Spectra of Lysozyme Heated at $150^{\circ} \mathrm{C}$ for Various Periods.

a) $5 \mathrm{~min}$, b) $20 \mathrm{~min}$, c) $50 \mathrm{~min}$.

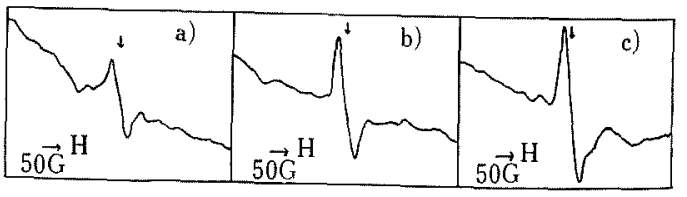

FIG. 3. ESR Spectra of Lysozyme Heated at $180^{\circ} \mathrm{C}$ for Various Periods.

a) $13 \mathrm{~min}$, b) $20 \mathrm{~min}$, c) $60 \sim 148 \mathrm{~min}$.

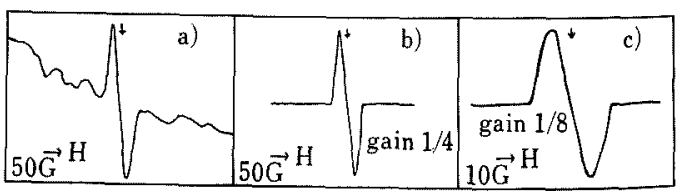

Fig. 4. ESR Spectra of Lysozyme Heated at $210^{\circ} \mathrm{C}$ for Various Periods.

a) $8 \mathrm{~min}$, b) $17 \mathrm{~min}$, c) $28 \mathrm{~min}$. 


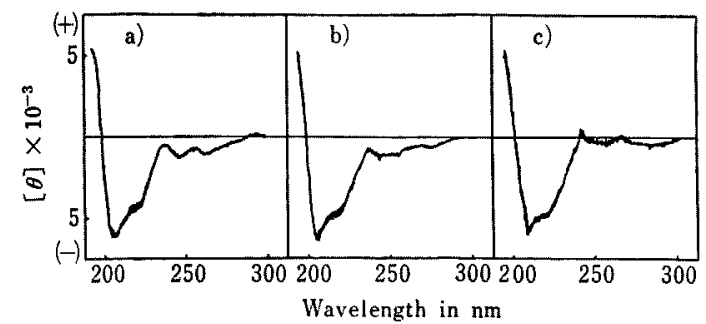

Fig. 5. CD Curves of Unheated and Heated Lysozymes.

a) unheated, b) heated at $150^{\circ} \mathrm{C}$, c) heated at $180^{\circ} \mathrm{C}$.

has a short life and disappeared immediately. As shown in Fig. 3, the amount of radicals produced during heating at $180^{\circ} \mathrm{C}$ increased up to $1 \mathrm{hr}$, and thereafter it was held constant. When lysozyme was heated at $210^{\circ} \mathrm{C}$, the signal intensity of the ESR responces remarkably increased without significant changes in both $g$-value and line width with the increase of heating time, as shown in Fig. 4.

\section{Circular dichroism of the heated lysozyme}

The changes in the secondary structure of lysozyme during heating were investigated through $C D$ curves. Figure 5 illustrates the $\mathrm{CD}$ curves of unheated lysozyme and those

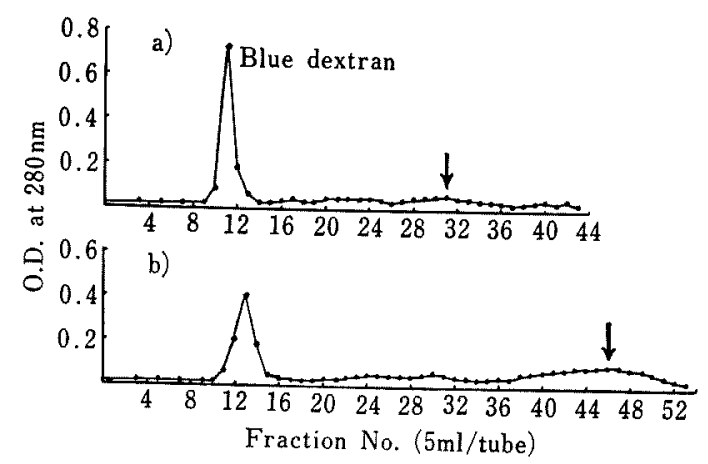

FIG. 7. Gel Filtration of the Heated Lysozyme on a Sephadex G-100 Column.

a) $200^{\circ} \mathrm{C}$, b) $230^{\circ} \mathrm{C}$.

of the lysozyme heated at 150 and $180^{\circ} \mathrm{C}$. The $\mathrm{CD}$ curves were almost the same as one another. Accordingly, it is considered that the secondary structure of lysozyme is not changed when it was heated below $180^{\circ} \mathrm{C}$.

\section{Gel permeation chromatography of the heated lysozyme}

Behavior of lysozyme on heating at various temperatures for $20 \mathrm{~min}$ was investigated by means of gel filtration. In the case of heating at 150 or $180^{\circ} \mathrm{C}$, the material was completely

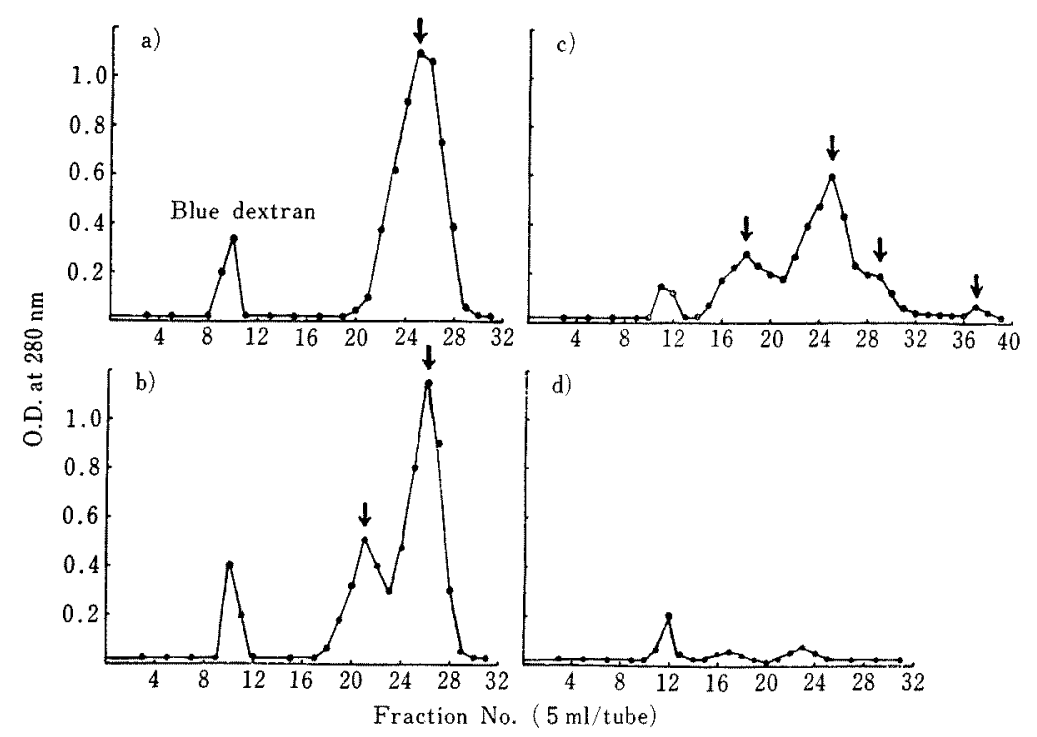

FIG. 6. Gel Filtration of Unheated and Heated Lysozymes on a Sephadex G-100 Column. a) unheated, b) heated at $150^{\circ} \mathrm{C}, \quad$ c) heated at $180^{\circ} \mathrm{C}, \quad$ d) heated at $190^{\circ} \mathrm{C}$. 
soluble in $8 \mathrm{~m}$ urea. On heating at $190^{\circ} \mathrm{C}$, the solubility of the material in $8 \mathrm{M}$ urea decreased, and over $200^{\circ} \mathrm{C}$, more than half the material became insoluble in $8 \mathrm{M}$ urea. The soluble fraction was used in the following experiment. Gel filtration was done using a Sephadex G-100 column equilibrated with $8 \mathrm{M}$ urea. The gel permeation chromatograms of the lysozyme unheated and heated at various temperatures are shown in Fig. 6. As a marker blue dextran of molecular weight $2 \times 10^{6}$ was used, and the changes in lysozyme during heating were detected from the retention volume. On heating at $150^{\circ} \mathrm{C}$, two peaks ap-
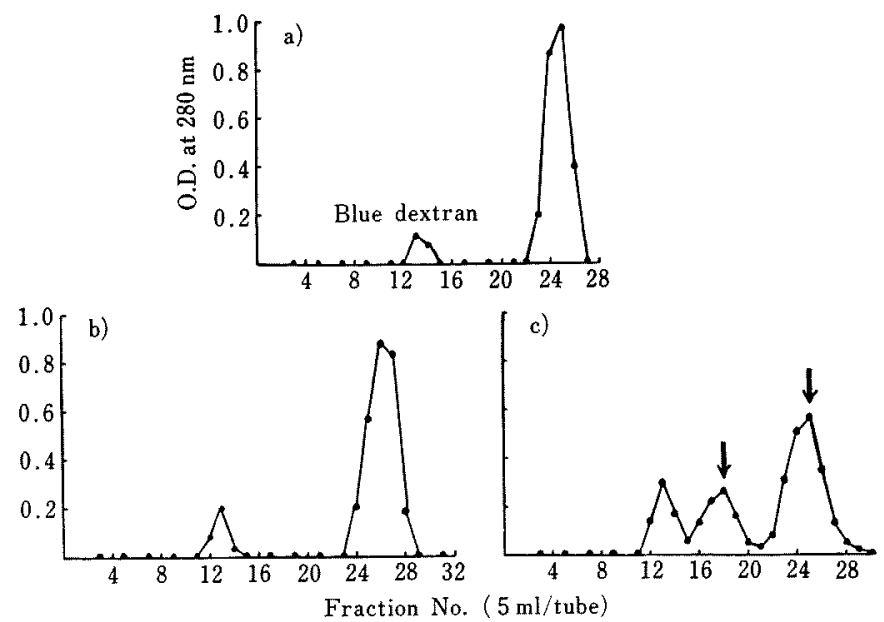

FIG. 8. Gel Filtration of Unheated and Heated Lysozymes on a Sephadex G-100 Column.

The samples were reduced with 2-mercaptoethanol, prior to the gel filtration. A column of Sephadex G-100, $2 \times 50 \mathrm{~cm}$, was equilibrated with $8 \mathrm{~m}$ urea $0.25 \%$ 2-mercaptoethanol. a) unheated, b) heated at $150^{\circ} \mathrm{C}$, c) heated at $180^{\circ} \mathrm{C}$.

Table I. The Amino Acid Composition of the Fractions from UNHEATED AND HeATED LySOZymes

The fractions was obtained through gel permeation chromatography on a Sephadex G-100 column (see Figs. $6 \sim 8$ ). The numbers indicate relative contents of each amino acid in molar ratio to that of leucine which is taken as 1.0 . - not detected.

\begin{tabular}{|c|c|c|c|c|c|c|c|c|c|c|c|}
\hline \multirow{3}{*}{$\begin{array}{l}\text { Amino } \\
\text { acid }\end{array}$} & \multicolumn{11}{|c|}{ Heating temperature and (fraction number) } \\
\hline & \multirow{2}{*}{$\begin{array}{l}\text { unheated } \\
(25)\end{array}$} & \multicolumn{2}{|c|}{$150^{\circ} \mathrm{C}$} & \multicolumn{4}{|c|}{$180^{\circ} \mathrm{C}$} & \multicolumn{2}{|c|}{$180^{\circ} \mathrm{C}$ (reduced) } & \multirow{2}{*}{$\frac{200^{\circ} \mathrm{C}}{(31)}$} & \multirow{2}{*}{$\frac{230^{\circ} \mathrm{C}}{(46)}$} \\
\hline & & $(21)$ & $(26)$ & (18) & $(25)$ & $(29)$ & (37) & (18) & $(25)$ & & \\
\hline Lys & 0.75 & 0.67 & 0.68 & 0.56 & 0.70 & 2.5 & 0.38 & 0.23 & 0.77 & 1.8 & 3.2 \\
\hline His & 0.13 & 0.12 & 0.13 & 0.04 & 0.09 & 0.37 & 0.05 & 0.03 & 0.11 & 0.25 & 0.37 \\
\hline Arg & 1.4 & 2.0 & 1.9 & 0.74 & 1.1 & 3.4 & - & 0.20 & 1.3 & 0.90 & 0.67 \\
\hline Asp & 2.6 & 2.6 & 2.6 & 2.0 & 2.3 & 3.8 & 2.3 & 2.2 & 3.1 & 2.9 & 2.1 \\
\hline Thr & 0.88 & 0.83 & 0.87 & 0.89 & 0.67 & 1.3 & 0.87 & 0.77 & 0.93 & 1.1 & 0.93 \\
\hline Ser & 1.3 & 1.5 & 1.6 & 2.4 & 1.1 & 2.9 & 2.7 & 1.5 & 1.5 & 3.0 & 3.7 \\
\hline Glu & 0.63 & 0.61 & 0.61 & 0.97 & 0.64 & 1.7 & 1.7 & 0.85 & 0.73 & 2.1 & 2.3 \\
\hline Gly & 1.5 & 1.7 & 1.6 & 2.4 & 1.3 & 3.6 & 3.3 & 1.8 & 1.7 & 2.7 & 3.8 \\
\hline Ala & 1.5 & 1.3 & 1.4 & 1.5 & 1.3 & 2.4 & 1.5 & 1.3 & 1.5 & 1.3 & 1.6 \\
\hline Val & 0.75 & 0.72 & 0.80 & 0.63 & 0.69 & 1.2 & 0.60 & 0.61 & 0.67 & 0.80 & 0.59 \\
\hline Ile & 0.75 & 0.87 & 0.91 & 0.69 & 0.73 & 0.89 & 0.67 & 0.77 & 0.73 & 0.91 & 0.93 \\
\hline Leu & 1 & 1 & 1 & 1 & 1 & 1 & 1 & 1 & 1 & 1 & 1 \\
\hline Tyr & 0.38 & & & 0.27 & 0.19 & & 0.17 & 0.18 & 0.25 & & - \\
\hline Phe & 0.38 & & & 0.31 & 0.34 & & 0.37 & 0.31 & 0.38 & & \\
\hline
\end{tabular}


peared, as shown in Fig. 6(b). It is assumed that the first peak corresponds to the polymerized fraction of lysozyme from its retention volume. As shown in Fig. 6 (c), when lysozyme was heated at $180^{\circ} \mathrm{C}$, four peaks were observed. The first peak is considered to contain the polymerized fraction. The slower moving two peaks probably contain degradation products. Accordingly, it is considered that both polymerization and degradation of lysozyme occur when it was heated at $180^{\circ} \mathrm{C}$. In the case of heating at $190^{\circ} \mathrm{C}$ (Fig. 6 (d)), the overall O.D. values at $280 \mathrm{~nm}$ is lower than the others owing to the decrease in solubility to $8 \mathrm{~m}$ urea. Figure 7 shows the gel permeation chromatograms of the lysozyme heated at 200 and $230^{\circ} \mathrm{C}$; the peaks became broad and the distribution in molecular weight extended.

To investigate the contribution of disulfide linkages to polymerization, the heated lysozyme was reduced with 2-mercaptoethanol. In order to avoid reoxidation in the column, $8 \mathrm{M}$ urea-0.25\% 2-mercaptoethanol was used as eluting solution. The result is illustrated in Fig. 8. When lysozyme was heated at $150^{\circ} \mathrm{C}$ (Fig. 8 (b)), the peak of tube number 18 to 22 (Fig. 6) disappeared. Therefore, the polymerization at $150^{\circ} \mathrm{C}$ is considered to be due to disulfide linkages. At $180^{\circ} \mathrm{C}$ (Fig.8 (c)), two peaks were observed, and the first peak is speculated to be a polymerized product for the most part through other combination than disulfide linkage.

The fraction indicated with an arrow in each chromatogram (Figs. $6 \sim 8$ ) was dialyzed against distilled water for $2 \sim 3$ days to remove the excess urea, and then hydrolyzed with $6 \mathrm{~N}$ $\mathrm{HCl}$ to determine the amino acid composition. The results are shown in Table I. The amino acid compositions of fraction No. 26 at $150^{\circ} \mathrm{C}$, fraction No. 25 at $180^{\circ} \mathrm{C}$ and fraction No. 25 at $180^{\circ} \mathrm{C}$ (reduced) which were eluted at the same position as that of unheated lysozyme, are all similar to that of unheated lysozyme. The fact that fraction No. 21 at $150^{\circ} \mathrm{C}$ is quite similar to fraction No. 26 at $150^{\circ} \mathrm{C}$ in the relative molar content of each amino acid support the idea that these fractions contain polymerized products through disulfide linkages. In fraction No. 18 at $180^{\circ} \mathrm{C}$, the relative molar contents of serine and glycine increased. The relative molar contents of serine, glutamic acid and glycine increased in fraction No. 29 and 37 at $180^{\circ} \mathrm{C}$, fraction No. 31 at $200^{\circ} \mathrm{C}$ and fraction No. 46 at

\section{Table II. Changes in Weight and Peptide BOND CONTENT OF LySOzYME DURING HeATING}

The lysozyme was heated for $20 \mathrm{~min}$ at the temperature shown. The figures indicate relative values taking the ones of unheated lysozyme as 100 , respectively. Peptide bond contents were determined by the Biuret reaction.

\begin{tabular}{lcc}
\hline & Weight & $\begin{array}{c}\text { Content of } \\
\text { peptide bond }\end{array}$ \\
\hline unheated & 100 & 100 \\
at $150^{\circ} \mathrm{C}$ & 96.3 & 95.8 \\
at $180^{\circ} \mathrm{C}$ & 93.8 & 94.2 \\
\hline
\end{tabular}

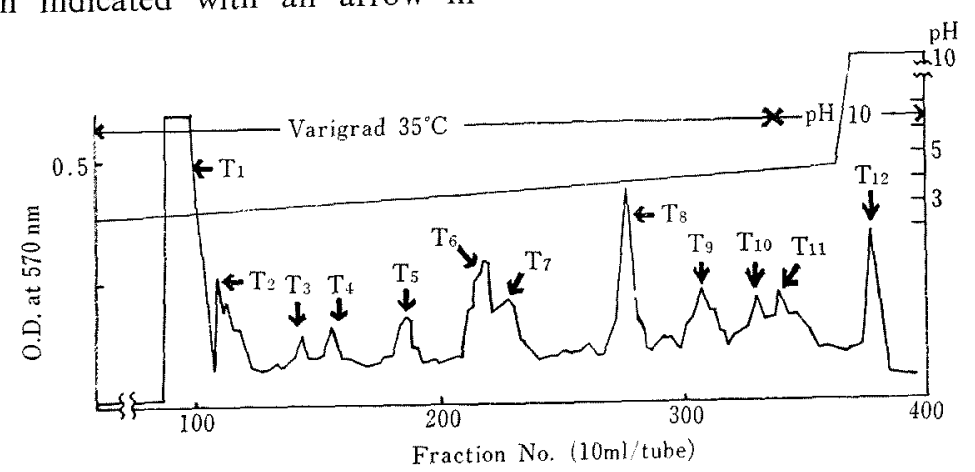

FiG. 9. Chromatogram of Tryptic Peptides from the Lysozyme Heated at $200^{\circ} \mathrm{C}$ on Dowex $50 \times 4$.

The lysozymes were reduced and carboxymethylated, prior to the tryptic hydrolysis. 
Table III. Amino Acid Contents of Tryptic Peptides from THE LYSOZYME HeATEd AT $200^{\circ} \mathrm{C}$ FOR $20 \mathrm{MTN}$

The tryptic peptides were obtained from the heated lysozyme as described in text.

\begin{tabular}{|c|c|c|c|c|c|c|c|c|c|c|c|c|}
\hline Amino acid & $\mathrm{T}_{1 \mathrm{~m}}$ & $\mathrm{~T}_{2 \mathrm{~m}}$ & $T_{3 m}$ & $\mathrm{~T}_{4 \mathrm{~m}}$ & $T_{5 m}$ & $\mathrm{~T}_{6 \mathrm{~m}}$ & $T_{7 m}$ & $T_{8 m}$ & $T_{9 m}$ & $T_{10 m}$ & $\mathrm{~T}_{11 \mathrm{~m}}$ & $T_{12 m}$ \\
\hline Lys & 1 & 1 & 1 & 1 & 1 & & & 1 & & 1 & & 1 \\
\hline \multicolumn{13}{|l|}{ His } \\
\hline Arg & & & & & & 1 & 2 & 1 & & & 1 & \\
\hline Asp & 4 & 1 & 1 & 3 & 1 & & 1 & 1 & & 1 & 2 & 1 \\
\hline Thr & 2 & 1 & 1 & 1 & 1 & 1 & & 1 & & 1 & 1 & \\
\hline Ser & 3 & 3 & 2 & 5 & 4 & 1 & 2 & 3 & & 2 & 3 & 1 \\
\hline Glu & 2 & 2 & 1 & 3 & 3 & & 1 & 2 & & 1 & 1 & 1 \\
\hline Pro & & & & & & 1 & & & 1 & & & \\
\hline Gly & 6 & 3 & 2 & 4 & 4 & 1 & 2 & 4 & & 2 & 3 & 1 \\
\hline Ala & 4 & 1 & 1 & 1 & 1 & & 1 & 2 & & 1 & 1 & 1 \\
\hline Val & 1 & & & & 1 & & & & & & & \\
\hline Ile & 2 & & & & 1 & & & & & & & \\
\hline Leu & 2 & & & & 1 & & & & 3 & 1 & 1 & \\
\hline Tyr & & & & & & & & & & & & 2 \\
\hline Phe & & & & & & & & & 1 & & & \\
\hline
\end{tabular}

$230^{\circ} \mathrm{C}$. In fraction No. 18 at $180^{\circ} \mathrm{C}$ and fraction No. 18 at $180^{\circ} \mathrm{C}$ (reduced), it is observed that the amino acid compositions differ somewhat from one another in the relative molar contents of lysine, arginine, serine and glycine. From the results mentioned above, it became clear that, when lysozyme was heated, both polymerization and degradation occurred.

\section{Determination of peptide bonds in the heated lysozyme}

Peptide bond contents in the lysozyme heated at 150 and $180^{\circ} \mathrm{C}$ were determined by the Biuret reaction. As shown in Table II, the amount of peptide bonds diminished in proportion to the decreased in weight of the heated lysozyme.

Above $200^{\circ} \mathrm{C}$, measurement was unsuccessful, as the sample were insoluble in the Biuret reagent.

\section{Tryptic hydrolysis of the heated lysozyme and} identification of peptide fragments

The lysozyme heated at $200^{\circ} \mathrm{C}$ for $20 \mathrm{~min}$ were reduced and carboxymethylated, and then hydrolyzed with trypsin, as described in materials and methods. The hydrolysate was subsequently separated on a Dowex $50 \times 4$ column. The result of the chromatography is shown in Fig. 9. Twelve peaks $\left(T_{1}\right.$ to $\left.T_{12}\right)$ were obtained. These peaks were further purified by PPC and TLC, and twelve peptides $\left(T_{1 \mathrm{~m}}\right.$ to $\left.T_{12 \mathrm{~m}}\right)$ were isolated. The analytical results of amino acid compositions in these peptides are summarized in Table III. Detailed discussion on the results is described below.

Enzymatic activity of the heated lysozyme

As an index of changes in the conformation of lysozyme, enzymatic activity of the heated lysozyme was determined. The results are indicated in Fig. 10. The lysozyme heated at 150 and $180^{\circ} \mathrm{C}$ produced 75 and $54 \%$ of $\mathrm{N}$-acetylglucosamine after $24 \mathrm{hr}$, respectively, as compared with the value corresponding to the unheated lysozyme. It is thus considered that, on heating below $180^{\circ} \mathrm{C}$, the conformation of lysozyme is still partially maintained.

\section{DISCUSSION}

By means of physical and chemical approaches various changes were observed on the heated lysozyme. Polymerization and degradation with cleavage of peptide bonds were clarified by the results of gel filtration, 


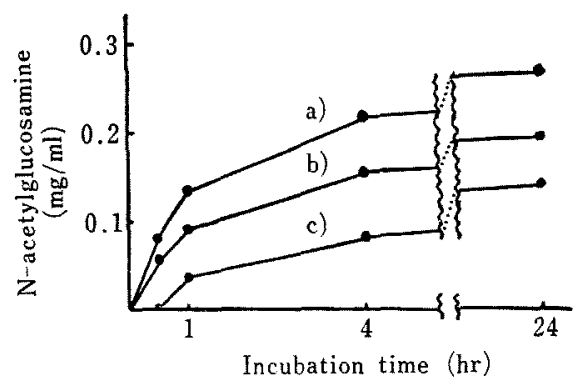

FIG. 10. Enzyme Activity of Unheated and Heated Lysozymes.

a) unheated, b) heated at $150^{\circ} \mathrm{C}$, c) heated at $180^{\circ} \mathrm{C}$.

infrared spectra and ESR spectra. The polymerization of lysozyme observed on heating at $150^{\circ} \mathrm{C}$ occurs through disulfide linkages, as presumed from the result shown in Figs. 6 and 8. A radical with a short life as shown in Fig.2 (a) is assigned to $\mathrm{S}$ radical from the result of gel filtration (Fig. 6). At $150^{\circ} \mathrm{C}$, change in the secondary structure was scarcely observed. Destruction of the tertiary or quaternary structure was considered to be yielded mainly from polymerization through intermolecular exchange of disulfide linkages, because the enzymatic activity decreased only $25 \%$ in comparison with that of native lysozyme.

At $180^{\circ} \mathrm{C}$, it was found that the amount of radicals increased, and polymerization through the intermolecular binding of lysozyme began to occur with the formation of radicals which were produced destruction of the side chain in lysozyme and elimination ${ }^{3 /}$ of the $\alpha$-hydrogen atom of amino acid residues. However, at this temperature, conformation of native lysozyme partially remained (Figs. 5 and 10).

On the other hand, when lysozyme was heated at $200^{\circ} \mathrm{C}$, radicals were formed rapidly and abundantly, and destruction of both peptide bonds and amino acid residues occurred violently. The carboxymethyl lysozyme prepared from the lysozyme heated at $200^{\circ} \mathrm{C}$ was hydrolyzed with trypsin, and the amino acid composition of each peptide fragment isolated was determined. It is presumed that $T_{6 m}$ (Table III) is the peptide fragment equivalent to amino acid residue No. $69 \sim 73$ in the primary structure of lysozyme. According to the result of the $\mathrm{X}$ ray analysis of lysozyme," this part corresponds to the one that is folded as it contacts irregularly with the pleated sheet (No. 41 54). The other eleven peptides do not correspond to any part of the primary structure. However, if we consider that the side chains of amino acid residues in protein are decomposed by thermal degradation and secondary products are formed ${ }^{10)}$ (for example, glycine, alanine, aspartic acid and serine residues are secondarily produced through degradation of primary amino acid residues), it is assumed that $T_{2 m}, T_{3 \mathrm{~m}}$ and $T_{8 \mathrm{~m}}$ may be produced from No. $33 \sim 44,32 \sim 40$ or $33 \sim 41$ and $31 \sim 45$ of the primary structure of lysozyme, respectively. These parts contain many hydrophilic amino acid residues and are stereochemically exposed on the molecular surface of lysozyme. $T_{1 \mathrm{~m}}, T_{4 \mathrm{~m}}, T_{5 \mathrm{~m}}, T_{7 \mathrm{~m}}, T_{9 \mathrm{~m}}, T_{10 \mathrm{~m}}, T_{11 \mathrm{~m}}$ and $T_{12 \mathrm{~m}}$ are difficult to be assigned in the primary structure of lysozyme. Formation of these peptide fragments may be explained by recombination of peptides produced or transpeptidation. As described in the previous report, ${ }^{103}$ in the thermal degradation of amino acid mixtures, some dipeptides were formed by condensation. Accordingly, in the present report, when lysozyme is heated, peptides different from the ones contained in the original materials are considered to be produced by recombination of peptides.

On heating above $200^{\circ} \mathrm{C}$, radical polymerization and degradation more strongly occur and the distribution in molecular weight of the heated lysozyme becomes broad (Figs. 4 and 7).

Acknowledgement. The authors wish to thank Dr. M. Kohno of Japan Electron Optics Laboratory, Inc., for measurements of ESR spectra.

\section{REFERENCES}

1) M. Fujimaki, H. Kato and F. Hayase, Agr. Biol. Chem., 36, 416 (1972).

2) F. Hayase, H. Kato and M. Fujimaki, ibid., 37, 191 (1973). 
3) F. Hayase, H. Kato and M. Fujimaki, J. Agr. Food Chem., in press.

4) A. G. Gornall, C. J. Bardawill and M. M. David, J. Biol. Chem., 177, 751 (1949).

5) R. E. Canfield, ibid., 238, 2698 (1963).

6) E. W. Yemm and E. C. Cocking, Analyst, 80, 209 (1955).
7) K. Hayashi, N. Yamasaki and M. Funatsu, $A g r$. Biol. Chem., 28, 517 (1964).

8) M. Somogyi, J. Biol. Chem., 160, 61 (1945).

9) D. C. Phillips, Proc. Natl. Acad. Sci., 57, 484 (1967).

10) F. Hayase, H. Kato and M. Fujimaki, Agr. Biol. Chem., 39, 741 (1975). 